The spectroscopic programme also seems to have been carried out successfully. The Daily Telegraph is to be congratulated upon its enterprise in obtaining direct information by radio of observations of an eclipse from a station more than 9,000 miles away. This very remarkable achievement merits a place in astronomical history.

\section{Blood Groups in Africa}

At the beginning of April, Dr. Ronald Elsdon-Dew and Mr. J. de Bruijne, of the South African Institute of Medical Research, left Johannesburg on a prolonged tour of investigation of the blood groups of African peoples, and more especially of the Bantu. They propose to examine various tribes in Southern and Northern Rhodesia, Nyasaland, Tanganyika, Kenya, the Anglo-Egyptian Sudan, Uganda and the Belgian Congo. Dr. Elsdon-Dew, who holds the appointment of assistant pathologist in the Medico-legal Department of the South African Institute of Medical Research, has been engaged on an intensive study of the African blood-groups since 1932, and has examined the blood grouping of more than five thousand South African Bantu. In publishing his results, and the somewhat startling inferences as to the racial history of Africa to which in his opinion they appeared to point, he emphasized the fact that theorizing on the serology of African peoples must of necessity be tentative, for in this respect Africa is still the Dark Continent. The present expedition has been undertaken to remedy the lack of material for purposes of comparison which gave to his ethnological argument a highly speculative character, more especially as regards the existence of a hypothetical primitive black race, possessing neither the $A$ nor the $B$ groups, to which his results appeared to point, and with which, serologically, the Southern Bantu apparently showed a closer affinity than any other people of which the blood groups were known. The expedition, which is travelling by motor caravan, will be at work for about six months.

\section{Local Archæological Studies in Nottingham}

Publication of the first annual report of the Excavation Section of the Thoroton Society of Nottinghamshire falls opportunely at a moment when attention has been directed in Parliament to the opportunity open to local archæological and scientific societies to educate their neighbours, the local authority and the local public generally, as to the desirability of preserving for posterity buildings and erections of historical or æsthetic interest and places of natural beauty (see Nature, Feb. 27, p. 345). The Excavation Section of the Thoroton Society has been formed as an outcome of the enthusiasm of a small number of students of the past history of the city of Nottingham, but more especially through the efforts of Mr. G. F. Campion, who was anxious that the work of local excavation carried out by himself and his father before him over a number of years should be placed on a permanent footing. Very wisely it was decided not to form a new society for this purpose, but to join forces with the Thoroton
Society, the long-established centre of archæological and antiquarian interest in the county. Thus the activities of the newly established section will be directed not only to continuing the work of excavation, but also to the expert examination and record of the numerous evidences of the city's past cultural history which are being brought to light with increasing frequency in the building operations in progress in connexion with the improvement and enlargement of business and other premises in Nottingham. It should at least be able to ensure that nothing worthy of note is overlooked-a matter of much importance in an area like Nottingham which is honeycombed with underground caves. The record of the first year's operations covers not only the excavations in Notting. ham's Norman and Plantagenet castle, and a Roman fortress, but also the supervision of excavations for building operations on eight sites, which produced some interesting samples of medieval pottery, including a fabric unknown from any other area and thought to be an exclusive product of Nottingham.

\section{Miocene Implements}

A NUMBen of years ago, the late Mr. Edward Westlake collected a very large series of specimens of flaked chert and flint from upper Miocene deposits at Aurillac, and other sites, in the Cantal, France. These specimens, which number several thousands, are now housed at the Museum, Ipswich, where they are being studied by Mr. Reid Moir. When his exam. ination of the collection is completed, Mr. Reid Moir proposes to describe it; but it may be said that a great many of the specimens exhibit, in a marked degree, certain characteristics which have been generally accepted as indicative of artificial shaping. Archæologists, and those interested in the antiquity of man, owe a debt of gratitude to Mr. Westlake's insight and care in getting together such a vast and important collection, which, from many aspects, is unique. There would seem to be no doubt as to the Upper Miocene age of the deposits from which the specimens were derived, and their adequate descrip. tion may well prove to be a significant contribution to the solution of the problem of the antiquity of the human race.

\section{Dry Crossings of the Nile}

With reference to the two letters to the Editor in Nature of June 5, p. 961, under the title "Dry Crossings of the Nile", from E. J. Wayland and Dr. H. E. Hurst, we have received the following from Dr. A. E. H. Tutton: "It may be of interest to add to the record of the observations by Dr. Wayland, from the air in 1930 and by an actual passage on foot in 1933, that a natural bridge does from time to time exist across the higher reaches of the Nile, strong enough to bear the elephant, a still more remarkable observation by my late brother-in-law, Mr. Leonard Loat, made and recorded by him in the year 1902, during his survey of the fishes of the Nile for Lord Cromer's Government and the British Museum (Natural History). In a letter to me 
describing the difficulties then being met with, owing to the remarkable density and solidity of the 'sudd' between Fashoda and Gondokoro, he states that he had just observed a herd of over two hundred elephants walking on the sudd over the river. When he returned to England for a short leave, before undertaking a similar survey up the Blue Nile, I asked him whether he had recorded a solid fact or was indulging in a traveller's tale, as it seemed a very extraordinary circumstance, if true. He was most emphatic, however, as to its being literally true, and that he had ceased to count the elephants after the two hundredth; also that he had been accompanied by a big-game hunter friend at the time, as well, of course, as by the Egyptian skipper and Sudanese crew of his little survey vessel, a specially fitted dahabeyah, all of whom were greatly interested in the unusual spectacle. It is referred to in the obituary notice of Mr. Loat's work which appeared in The Times of April 30, 1932."

\section{Memorial Tablet to Telford}

DURING the conversazione of the Institution of Civil Engineers held on June 2, the president, Sir Alexander Gibb, unveiled a small tablet in the newly completed extension of the main library recalling Telford's gift of books to the Institution. When Telford accepted the presidency in 1820, he wrote: "As proof of my sincere desire to promote the prosperity of the Institution, I beg leave to present it a collection of Books connected with the profession of a Civil Engineer ; they will form no inconsiderable portion of a suitable library, destined, I trust, at no distant period to become a valuable one. . . ." The library now contains 62,300 volumes, and Telford's books, with some others, have been placed in cases under the window in the west wall of the extension. Hollin's bust of Telford stands on the top of the cases, just above the tablet recalling his gift, while the oil paintings which the great engineer bequeathed to the Institution of the Pont Cysylltau Aqueduct and the Menai Bridge have been hung one on each side of the window.

\section{Hooker's Aneroid Barometer}

THE British Association has recently received from Miss Hooker, daughter of Sir Joseph Hooker, a gift of the aneroid barometer which used to hang by the fireplace in Charles Darwin's 'old study' at Down House, where it will now be replaced. A small repair has been kindly carried out by Messrs. Negretti and Zambra, and the aneroid is in working order. The face bears the words "Holosteric Barometer" and beneath them the figure 19, but no maker's name; the usual verbal indications of weather conditions are provided, and the dial is graduated continuously round the whole circle, figured from 25 in. up to 31 in., the remaining arc, between 31 and 25 in., being also graduated, as the whole scale is, in fiftieth parts of an inch. A small label, affixed perhaps when the instrument came into Hooker's possession, bears the name of "C. Darwin".

\section{New Central Botanical Gardens for Moscow}

Botanical gardens, to be known as the Central Botanical Gardens of the U.S.S.R., will shortly be constructed on the southern and northern slopes of the Lenin Hills, on the outskirts of Moscow, according to the Soviet Union Year Book Press Service. The gardens will occupy a site of 825 acres, bounded by the projected Rublevskoye Chaussee, the Palace of Soviets, the Andreyev Canal and the Moscow River. A considerable part of the site will be used as a scientific research station. Special hothouses and structures will be put up in this section for the purpose. The middle of the Gardens will have a group of hothouses with varying artificial climates for the growing of plants from all over the world. A model orchard will be used for showing Michurin and other horticultural experiments. The Botanical Gardens will be attractively laid out with terraces, fountains and waterfalls. A funicular railway will connect the Moscow River Embankment with the top of the Lenin Hills. The Academy of Sciences of the U.S.S.R. has appointed a special commission to take charge of the designing and construction of the Gardens. The Commission includes V. L. Komarov, president of the Academy, Prof. N. I. Vavilov, Prof. B. A. Keller, A. M. Lezhav, director of the Central Department of Sub-Tropical Crops of the Com. missariat of Agriculture of the U.S.S.R., and I. S. Gorshkov, director of the Michurin Central Laboratory of Genetics.

\section{Future of the Coal Gas Industry}

THE seventy-fourth annual meeting of the Institution of Gas Engineers was held on June 1-4, under the presidency of Mr. Stephen Lacey, of London. The papers contributed illustrated the problems and trends of the gas industry to-day-the tendency gathering in momentum on one hand to replace the consumption of raw coal by smokeless fuels and methods, and on the other to use fuels in a 'fluid' form amenable to ready and automatic control. The gas industry as a producer of smokeless fuels-both solid and fluid-is deeply involved in this trend, and the papers read retailed divergent opinions as to the future. A major problem of the industry is to maintain an economic balance between coke and gas. In Great Britain, gas engineers do not anticipate an early displacement of solid fuels; the industry must look for a combination of the two. Mr. C. F. Broadhead, of Melbourne, Australia, influenced by the acute instability of markets for by-products in that country, favoured concentration on complete gasification of coal. This idea, which is by no means new, is attracting renewed attention, and as $\mathrm{Mr}$. Lacey said, is now the aim of an important branch of the Institution's research work. The uncertainty about the future of the supplies of suitable gas coal has stimulated interest in this problem. It has long been felt that the service of the gas industry would be more efficiently rendered if organized into larger units. Such an organization of the electrical industry has been imposed by law and a somewhat analogous process is now proceeding in the gas industry, but 